\title{
SINGLE EVENTS AND CENTURY-SCALE EVOLUTION OF THE NORTHERN MARGIN OF THE TAGUS RIVER BEFORE THE BOAVISTA LANDFILL: A MULTIDISCIPLINARY APPROACH TO A NATURAL AND ANTHROPIC SEDIMENT RECORD
}

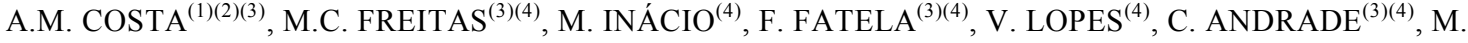 \\ CACHÃO ${ }^{(3)(4)}$, P.M. MENDES ${ }^{(1)}$, A. SARRAZOLA ${ }^{(5)}$, M. MACEDO $^{(5)}$, J. BETTENCOURT $^{(6)}$, R. CARVALHO $^{(5)}$ \\ \& T. FREITAS ${ }^{(5)}$
}

Abstract: In this work we present preliminary results of the study of one sediment core (EDP1), collected near Cais do Sodré,
Lisbon downtown, close to the present day Tagus riverfront. The results allowed differentiation of 4 major sediment
units that present a signature of increasing anthropic influence over time. The lowermost unit (Unit 1 ) corresponds to a
subtidal flat accreting in low energy and brackish conditions. This sedimentation pattern is interrupted by high-energy
deposition of Unit 2 , characterized by higher density and diversity of the foraminiferal content and high content of
other bioclasts remains (Sub-unit $2 A$ ) and by the incorporation of several anthropic elements, such as $17^{\text {th }}-18^{\text {th }}$ century
ceramics (Sub-unit $2 \mathrm{~B}$ ). Given the radiocarbon chronological framework and type and dates of the anthropic materials
included in both sub-units of Unit 2 , they are tentatively related with either the 1724 extreme storm and/or the 1755
tsunami. The abrupt drop in coccolith densities in this unit is compatible with an increase in sedimentation rate. Later
sedimentation (Units 3 and 4 ) mirrors increasing energy in comparison with Unit 1 , reflecting the shallowing of the
study area and shift towards upper subtidal conditions, the natural sedimentation having been interrupted in the middle
$19^{\text {th }}$ century by the placement of an artificial infill that reclaimed the estuarine margin.
The interpretation presented here was developed in the framework of the Lisbon Stories project, which addresses the
relationships between the Tagus, the city of Lisbon and its people throughout the last few centuries.

Keywords: Estuarine margin, Lisbon, sedimentology, foraminifera, calcareous nannofossils, anthropic influence.

Resumo:

\begin{abstract}
Eventos extremos e evolução secular da margem norte do Rio Tejo antes da construção do Aterro da Boavista: uma abordagem multidisciplinar ao registo sedimentar de origem natural e antrópica

Neste trabalho apresentamos os resultados preliminares do estudo de uma sondagem (EDP1) recolhida nas proximidades do Cais do Sodré, na zona baixa de Lisboa, junto à actual margem ribeirinha do Tejo. Estes resultados permitiram a diferenciação de 4 unidades sedimentares principais que mostram um aumento da assinatura antrópica no sedimento ao longo do tempo. A unidade da base (Unidade 1) corresponde a um sedimento depositado em condições estuarinas, num ambiente subtidal de baixa energia. Este padrão de sedimentação é interrompido pela deposição da Unidade 2, que reflecte mais alta energia. Esta unidade é caracterizada por um aumento na densidade e diversidade de espécies de foraminíferos e em bioclastos (Sub-Unidade 2A) e pela incorporação de vários elementos antrópicos (fragmentos de cerâmica atribuídos aos séculos XVII e XVIII) (Sub-unidade 2B). A datação por radiocarbono de fragmento de madeira e a data atribuível aos fragmentos de cerâmica, sugere que a deposição da Unidade 2 pode ter resultado de uma tempestade extrema que ocorreu a 19 de Novembro de 1724 e/ou ao tsunami de 1 de Novembro de 1755. O decréscimo abrupto na densidade de cocólitos na Unidade 2 é compatível com um aumento na taxa de sedimentação. A sedimentação posterior a este evento (Unidades 3 e 4) espelha um retorno às condições estuarinas subtidais mas revela um aumento de energia em relação à Unidade 1, reflectindo uma menor profundidade da coluna de água com passagem para um ambiente subtidal superior. A sedimentação natural na área de estudo é interrompida durante a segunda metade do século XIX com a construção do Aterro da Boavista, um aterro artifícial construído com o intuito de reclamar terra ao rio.
\end{abstract}

Palavras-Chave: Margem estuarina, Lisboa, sedimentologia, foraminíferos, nanofósseis calcários, influência antrópica.

Received: 8 April, 2016; Accepted: 3 May, 2016

\section{INTRODUCTION}

In the area of the municipality of Lisbon, there are several archaeological evidences of $\mathrm{Pa}$ laeolithic hunter-gatherer communities. However, the city centre started to grow continuously only since the Iron Age (Fig. 1; e.g. BUGALHÃO, 2015), the first known archaeological records from both maritime and fluvial traffic in connection with the Tagus estuary (e.g. BLOT 2003) dating from that period.

From the Iron Age onwards the city was occupied continuously as testified by the pre-Roman and Roman artefacts found in numerous Lisbon locations (e.g. AMARO 1993; CARDOSO 1995;

\footnotetext{
${ }^{(1)}$ LARC - Laboratório de Arqueociências/DGPC, Rua da Bica do Marquês n², 1300-087 Lisboa, Portugal. Email do autor correspondente: acosta@dgpc.pt

${ }^{(2)}$ EnvArch/CIBIO/InBIO, Rua da Bica do Marquês n², 1300-087 Lisboa, Portugal

(3) IDL - Instituto D. Luís, Faculdade de Ciências, Universidade de Lisboa, Campo Grande, Edifício C6, Piso 3, Campo Grande, 1749-016 Lisboa, Portugal

(4) Departamento de Geologia, Faculdade de Ciências da Universidade de Lisboa, Campo Grande, Edifício 6, Piso 3, Campo Grande, 1749-016 Lisboa

(5) ERA-Arqueologia, Calçada de Santa Catarina, 9C, 1495-705 Cruz Quebrada, Portugal

${ }^{(6)}$ CHAM - Faculdade de Ciências Sociais e Humanas, Universidade Nova de Lisboa e Universidade dos Açores, Avenida de Berna, 26C, 1069-061 Lisboa
} 


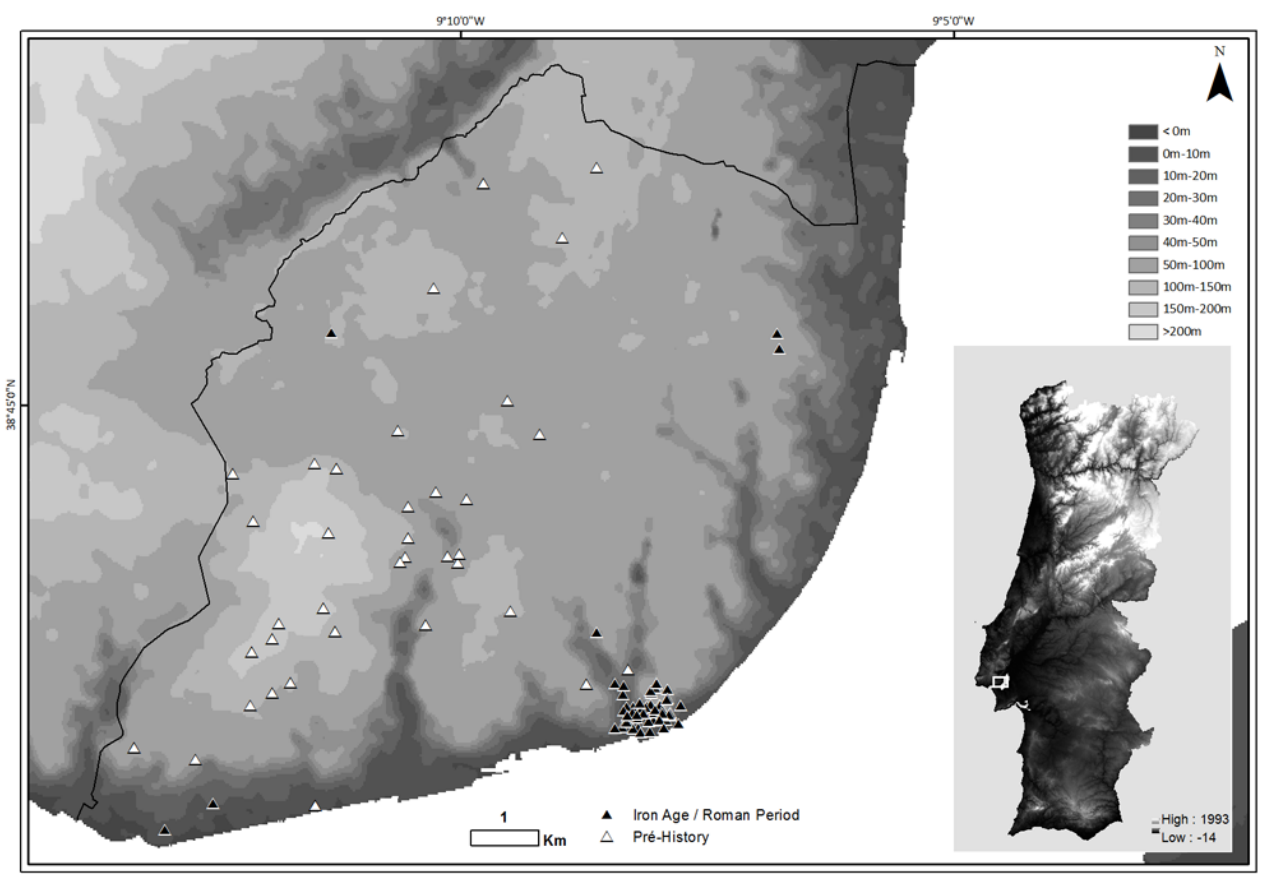

Fig. 1. Hypsometry of Portugal and Lisbon city, with archaeological sites in the municipality of Lisbon. After Portal do Arqueológo, Direção-Geral do Património Cultural (DGPC). Black solid line - limit of Lisbon Municipality.

Fig. 1. Hipsometria de Portugal e de Lisboa com a localização dos sítios arqueológicos no Concelho de Lisboa. Informação do Portal do Arqueológo, Direção-Geral do Património Cultural (DGPC). Linha sólida preta - limite do Concelho de Lisboa.

FABIÃO 1998; BUGALHão 2001, 2008; SOUSA 2014). These remnants form an overlapping archaeological record that Bugalhão (2015) referred to as the "overlapping city". Several archaeological findings dated from the Iron Age to the Roman Period spread all over the old city and show evidences of contact with foreign societies and of strong connections with fluvial and maritime activities (e.g. AMARO 1993; CARDOSO 1995), indicating Lisbon as an important commercial seaport (Diogo \& TRINDAde 1999). It is also since Roman ages that the riverfront area started to be manipulated by man (e.g. AMARO 1993; BLOT 2003; ALMEIDA et al. 2009). Several archaeological findings from the Roman Period are known in the area of Esteiro da Baixa (EB; e.g. AMARo 1995), the downstream valley section collecting two important fluvial tributaries of the Tagus River - Arroios and Vale do Pereiro streams (Fig. 2). Studies performed in a $43 \mathrm{~m}$-long core collected at EB (core PC98, see point 9 in Fig. 2) show the natural sedimentation pattern of this valley when it was drowned by marine water in consequence of the rise in sea level that followed the Last Glacial Maximum (LGM, ca. 18000 cal BP). In the top $10 \mathrm{~m}$ of this core, dated from Roman times onwards, the sediment shows strong anthropic influence (Roman artifacts and evidences of dredging or excavation events performed during this period, followed by circa $7.5 \mathrm{~m}$ of artificial infillings) (ALMEIDA et al. 2009).
The expansion of Lisbon continued until present and the link between the city, the Tagus River and the Atlantic Ocean is obvious, as extensively described by Blot (2003).

It is also known that the city of Lisbon have often been struck by extreme events such as high intensity storms (e.g. SARRAZOLA 2013) and tsunamis following seismic activity (e.g. GUTSCHER et al, 2006; MIRANDA et al. 2012). Sediment layers related with extreme events on the northern Tagus margin are scarce, but deposits associated with the 1531 and 1755 tsunamigenic events have been described in the Lisbon area (e.g. ANDRADE et al. 2003; RAMOS-PEREIRA et al. 2013).

Lisbon Stories is an unfinanced project coordinated by the Archaeosciences Laboratory (LARC/DGPC and EnvArch/CIBIO/InBIO) and by the Geology Department and IDL research center of the Faculty of Sciences of University of Lisbon (DG-FCUL/IDL). Its main goal is to characterize the environmental evolution of the northern margin of the Tagus estuary and the relationships between the Lisbon People and the River through time. It started in 2011 during the archaeological excavation by ERA-Arqueologia of a $17^{\text {th }}$ century tide grid, that was exhumed in Praça D. Luís I (Cais do Sodré; SARRAZOLA et al., 2013) during city works. This structure was buried below several meters of landfills and ruins of historical buildings (e.g. SARRAZOLA et al., 2013) - a fragment of the overlapping city - and rested above muddy sediments de- 
posited in a tide-dominated, low-energy estuarine environment. The study of these sediments became especially important to inform on questions emerging from the archaeological studies: how was the local landscape during the period of construction and usage of the tide grid, and before the $17^{\text {th }}$ century? How did the increasing anthropic activities in the riverfront influenced the fluvial dynamics in that area? By other hand, sediment cores and samples collected in the pre-artificial Tagus margin can bring new insights regarding sediment layers derived from extreme events embedded in the permanent sedimentary column. Did sediments deposited in the Tagus margin register extreme events of coastal flooding?

Since 2011 several sediment cores and samples have been collected during salvage excavations in archaeological sites found along the Lisbon waterfront in order to reconstruct the evolution of the northern riverine margin of the Tagus River, pre- and post-dating the archaeological findings.
Samples from 7 archaeological sites were already collected (Fig. 2): Ribeira das Naus, Rua do Arsenal, Praça D. Luís I (Cais do Sodré), Nova Sede da EDP (Cais do Sodré), Largo Conde Barão, Bar/ Restaurante BBC/Piazza Di Mare and CAT Belém (EDP). It is worth mentioning that Lisbon Stories is part of a multidisciplinary project directed by ERA-Arqueologia that includes researchers from diverse research centers (CHAM, LARC/EnvArch, DG-FCUL/IDL, ISA, ITN, IST and CINAV) and is frequently named as Lisboa Ribeirinha.

In this work we present the first results produced in the framework of the project Lisbon Stories, a fragment of the story of Lisbon imprinted in the sediments of EDP1 core (Fig. 2). Physical, chemical, palaeoecological and chronological analysis were performed on the recovered sediments to infer on the local hydrodynamic conditions, organic matter source and geomorphological settings of the study area.

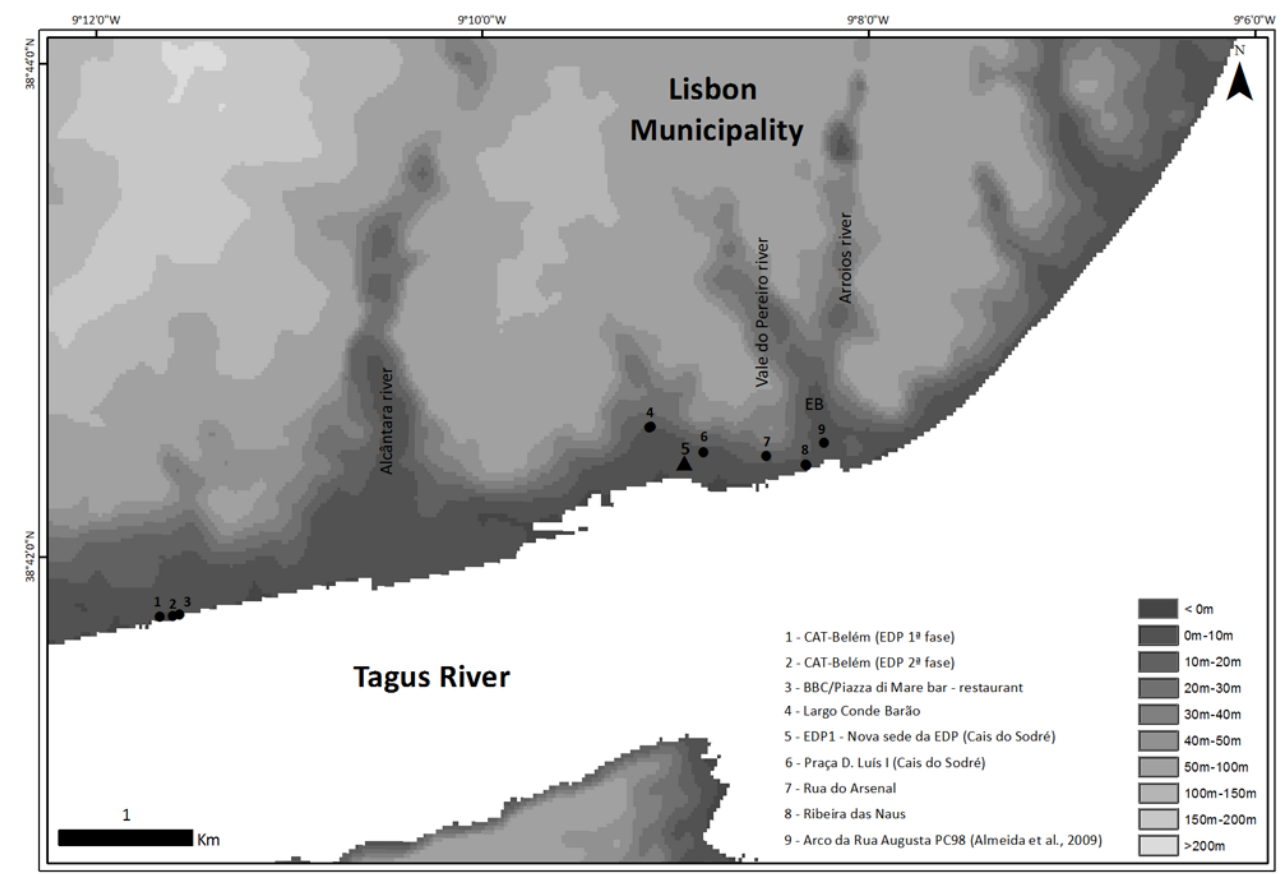

Fig. 2. Hypsometry of study area and location of all the sediment cores and samples collected within the frame of the Project Lisbon Stories. Point 5 shows the location of core EDP1. Important morphological structures (valleys) identified in the text were referred in this figure. EB - Esteiro da Baixa (correspond to an old tributary humid lowland).

Fig. 2. Hipsometria da área de estudo e localização de todas as sondagens e amostras de sedimento recolhidas no âmbito do projecto Lisbon Stories. O Ponto 5 indica a localização da sondagem EDP1. Estruturas morfológicas importantes (vales) identificadas no texto são referidas nesta imagem. EB - Esteiro da Baixa.

\section{STUDY AREA}

EDP1 sediment core was collected just north of Cais do Sodré, at the construction work place of Nova Sede da - EDP (Fig. 2). In this area several archaeological evidences dating from the Roman period to the $19^{\text {th }}$ century were found and excavated by the archaeological team together with researchers from CHAM (Centro de História D'Aquém e D'Além-Mar, FCSH), including deposits related to anchorage and landing activities. They include several anchors and scattered ceramics, glasses and organic artifacts, besides two vessels - Boavista 1 and Boavista 2, attributed to the $17^{\text {th }} / 18^{\text {th }}$ century (SARRAZOLA et al. 2013). Core EDP1 was col- 
lected below the Aterro da Boavista, a $19^{\text {th }}$ century landfill constructed to reclaim estuarine areas. The construction period and extension of Aterro da Boavista is documented in old cartographic documents (Fig. 3 and 4) and can be estimated by map comparison.

In figure 3, EDP1's location was plotted in a georeferenced database constructed upon the 1844 plan of Lisbon (Planta de Lisboa, unknown author,
Augusto Vieira da Silva collection; georeferenced map courtesy of Câmara Municipal de Lisboa CML; e.g. OLIVEIRA 2012). In this map it is possible to see the post-1755 reconstructed Lisbon, in particular the area corresponding to downtown, and the linearized development of the northern estuarine margin indicating that it had been extensively artificialized before 1844. In this map, EDP1 is located under water, in the estuarine subtidal zone.

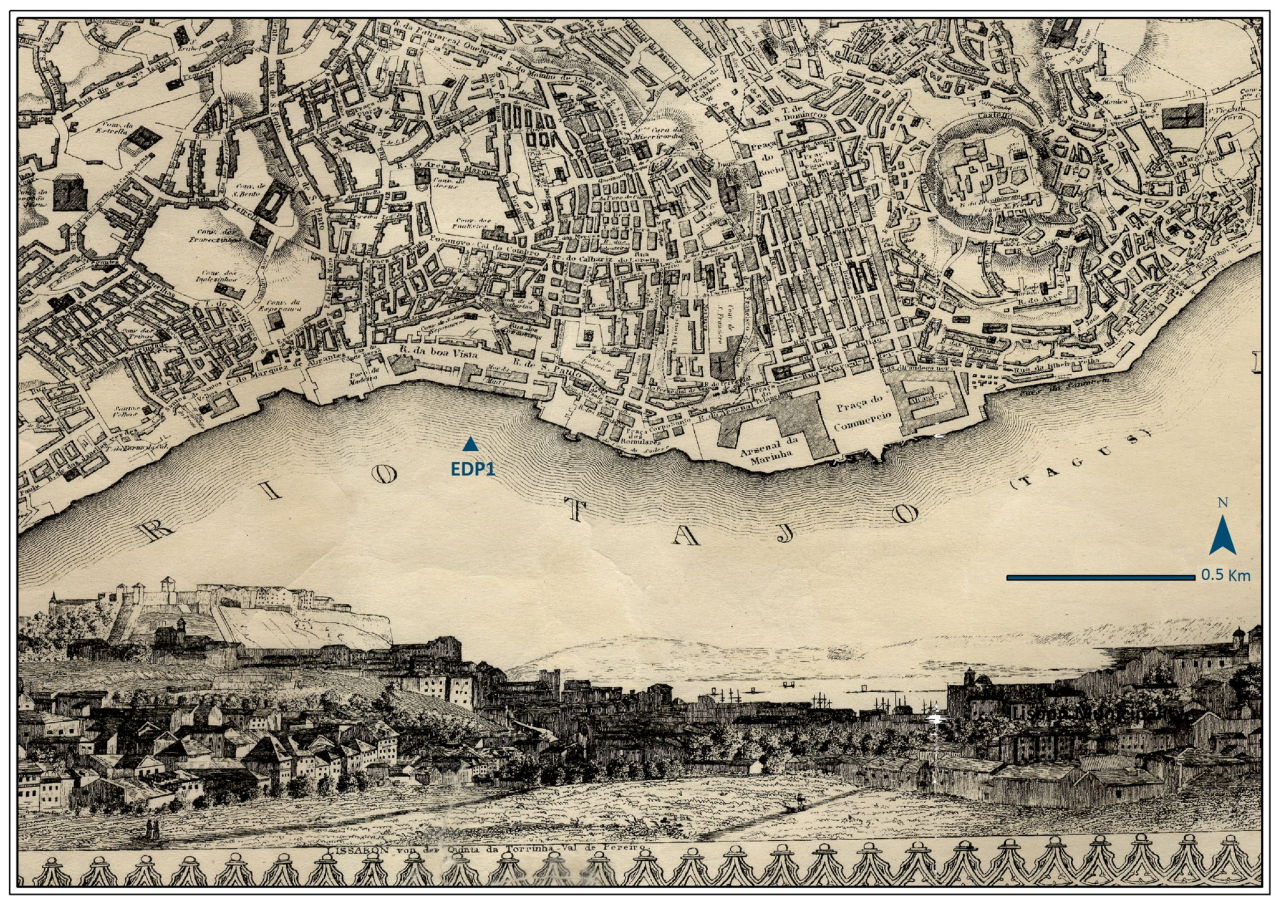

Fig. 3. Map of Lisbon from 1844, unknown author. Collection of Augusto Vieira da Silva. Georeferenced map courtesy of Câmara Municipal de Lisboa. Position of EDP1 core is indicated in the map.

Fig. 3. Mapa de Lisboa de 1844, autor desconhecido. Colecção de Augusto Vieira da Silva. Mapa georeferenciado cortesia da Câmara Municipal de Lisboa. A posição da sondagem EDP1 está localizada no mapa.

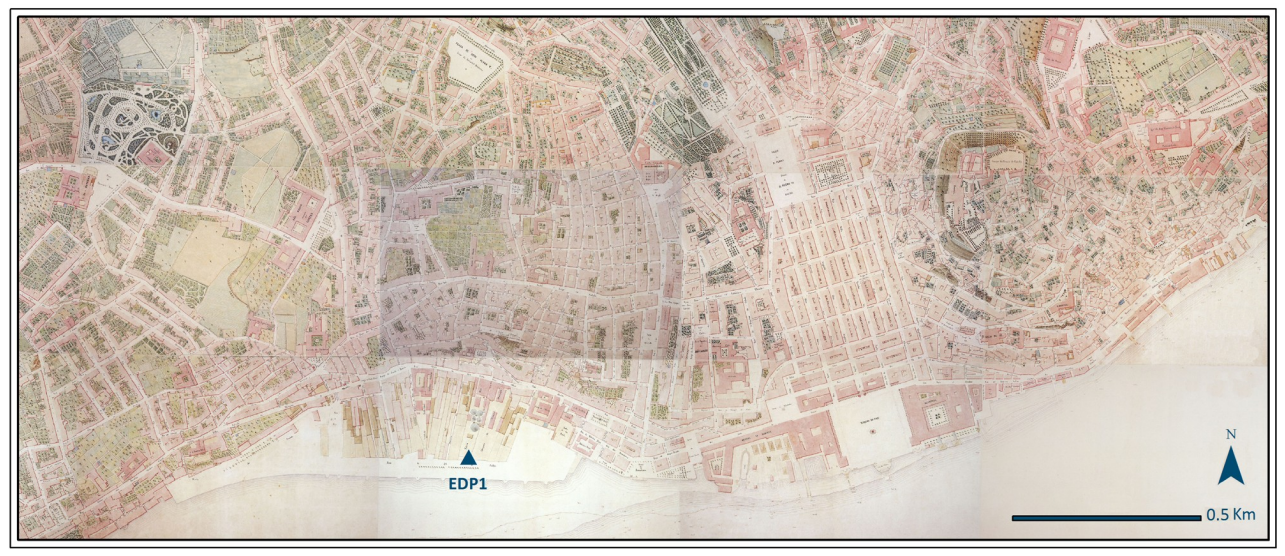

Fig. 4. Filipe Folque topographic map of Lisbon - Carta Topográfica da Cidade de Lisboa, 1856-58. Collection of Augusto Vieira da Silva. Georeferenced map courtesy of Câmara Municipal de Lisboa. Position of EDP1 core is indicated in the map.

Fig. 4. Mapa topográfico de Lisboa, Filipe Folque - Carta Topográfica da Cidade de Lisboa, 1856-58. Colecção de Augusto Vieira da Silva. Mapa georeferenciado cortesia da Câmara Municipal de Lisboa. A posição da sondagem EDP1 está localizada no mapa. 
In figure 4 EDP1 was plotted on the 1856-58 topographic map of Filipe Folque (Carta Topográfica da Cidade de Lisboa, Augusto Vieira da Silva collection; georeferenced map courtesy of CML; e.g. OLIVEIRA 2012). This map shows that the Aterro da Boavista landfill has been extended further south of the core location and study area. The cartographic data above constrain the seaward expansion of that landfill to the coring site to the 1844-1858 time window. Field observations show that in this location, the landfill includes residues of naphtha and tar associated to the operation of the gas plant of Boavista that was built in 1846 .

The Holocene/Pleistocene sediments sampled in EDP1 rest upon an erosive surface truncating Miocene (Aquitanian/ Early Burdigalian) overconsolidated clays and marls (PAIS et al. 2006). At the coring site, the contact between the Miocene basement and the Quaternary deposits rests at around $10 \mathrm{~m}$ below mean sea level ( $\mathrm{bmsl}$ ) (MOTA-ENGIL 2012).
A topographic profile trending NNE-SSW was produced using the software ArcGIS $10 \AA$ and a 25m-resolution Digital Terrain Model (DTM) to investigate the relationship between the local topography and EDP1 (Fig. 5). Coupling the information made available in Mota-Engil (2012) geotechnical report with the topographic data, it is possible to reconstruct the morphology of the area surrounding the coring location prior to the infilling works. The estuarine margin consisted of a hill (accommodating the Bairro Alto neighbourhood) directly confining with the estuarine water. The southern hill slope plunged into the river and it became near-horizontal at the top of estuarine sediment accumulated in the northern margin. At the EDP1 location the estuarine sediment developed within the subtidal zone. The construction of the Aterro da Boavista raised and levelled the land surface adjacent to the hill slope to about $3 \mathrm{~m}$ above mean sea level (amsl) across ca. $250 \mathrm{~m}$. To the NNW a small rivulet tributary of the Tagus River flows into the studied area.

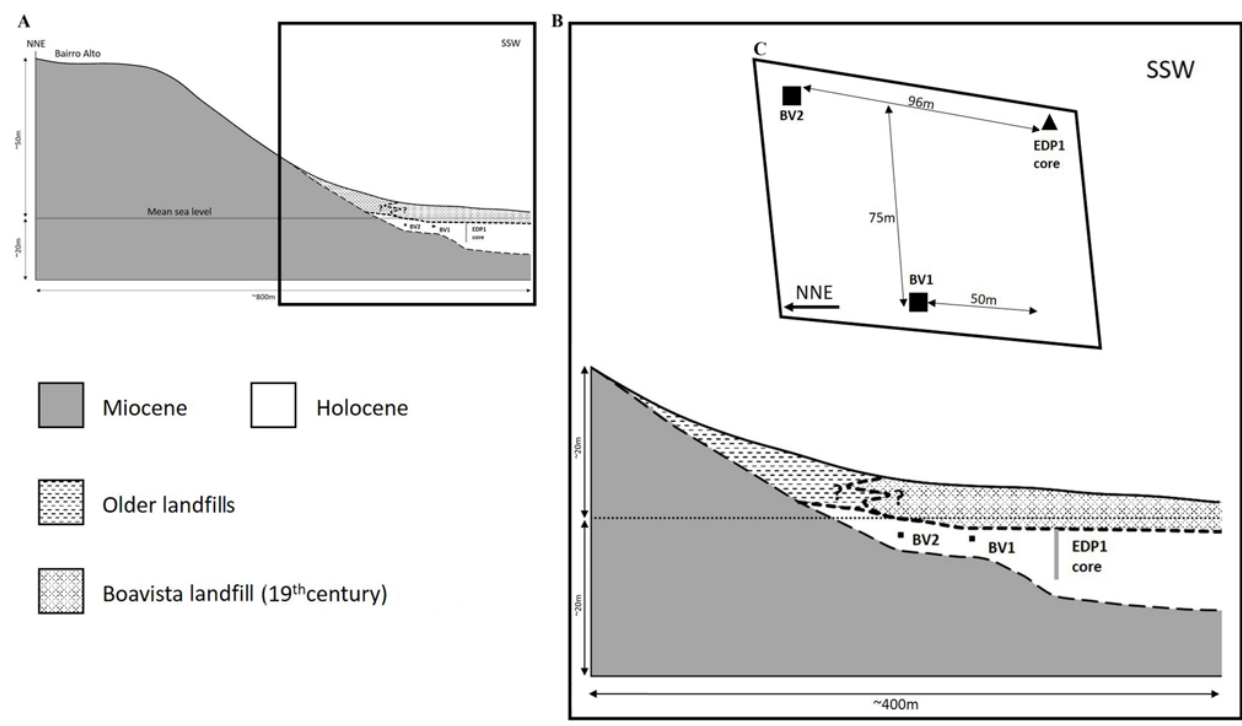

Fig. 5. A - Schematic profile between Bairro Alto and the end of Aterro da Boavista; B - Expanded view of the studied area; C - EDP1 core position in relation with the vessels Boavista 1 (BV1) and Boavista 2 (BV2). Fig. 5. - A - Perfil esquemático entre o Bairro Alto e o fím do Aterro da Boavista; B - Vista ampliada da área de estudo; C - Posição da sondagem EDP1 em relação com os navios Boavista 1 (BV1) e Boavista 2 (BV2).

\section{MATERIALS AND METHODS}

EDP1 core was collected using a Van der Horst sampler and a gauge-auger, starting at 170 $\mathrm{cm}$ bmsl just beneath the base of the Aterro da Boavista and extending down to $750 \mathrm{~cm} \mathrm{bmsl}$. Core sections were properly sealed and preserved at $4^{\circ} \mathrm{C}$ until analysis.

In the laboratory, EDP1 was opened, described, photographed, sub-sampled each 2 centimetres and freeze-dried. Sixty-three sub-samples were analysed for: 1) pH (LNEC, 1967; alkalinity characterization followed CosTA 1991); 2) determination of sediment coarse $(>63 \mu \mathrm{m})$ vs. fine fraction (ff; $<63 \mu \mathrm{m}$ ) by wet sieving using a standard
$63 \mu \mathrm{m}$ sieve; 3$)$ calcium carbonate $\left(\% \mathrm{CaCO}_{3}\right)$ using an Eijkelkamp calcimeter that measures the $\mathrm{CO}_{2}$ produced by the reaction with $[4 \mathrm{~mol} / \mathrm{L}] \mathrm{HCl}$ and; 4) organic matter contents (\% OM) using an incineration method adapted from Kristensen (1990) and including determination of labile and refractory fractions of $\mathrm{OM}$ burned at $280^{\circ} \mathrm{C}$ and $520^{\circ} \mathrm{C}$ for $6 \mathrm{~h} . R p$ Index is considered a semiquantitative measure and was used as an indicator of the organic matter source:

$$
\text { (1) } R p=\frac{\% \text { refractory } O M}{\% \text { total } O M}
$$


The coarse fraction of sediment was observed under a Leica NZ12 stereo microscope for the (qualitative) composition of sand-sized particles.

Thirteen samples were analysed for foraminifera (identification and count). Approximately $20 \mathrm{~g}$ of each sample were dried, weighted and washed through a $63 \mu \mathrm{m}$ sieve with tepid tap water to remove clay and silt following the standard methodology in foraminiferal studies (e.g. MURRAY 2006). The sieve was immersed in a methylene blue solution before each washing to prevent contaminations. Foraminiferal identification was made under a stereo microscope Olympus SZX12, following Loeblich and Tappan (1988) to generic classification and several publications for specific classification (e.g. MURRAY 1971; DEBENAY 2012). The procedure is finished when the sample is completely sorted or 300 specimens are observed (FATELA \& TABORDA 2002). The species were considered dominant when they represent $>10 \%$ of the assemblage in the same unit, subsidiary when they do not reach always $>10 \%$, minor when they correspond to $<10 \%$ (MURRAY 2007); the rare species counting $<5 \%$ were represented as Others. Foraminiferal density $(\mathrm{N} / \mathrm{g} ; \mathrm{N}=$ specimens) was determined and the Shannon Index (SHANNON 1948) was used to measure the species diversity of each sample.

Fifty seven samples were selected along the entire core, almost coincident with the ones analyzed for sedimentology, for determination of the densitiy on calcareous nannofossils. Samples were prepared according to Flores \& Sierro (1997) adapted for transitional environments (FERREIRA \& CACHÃO 2003) with $0.5 \mathrm{~g}$ of raw sample and $0.5 \mathrm{ml}$ of suspension to be injected into the Petri dish for random settling. A $30 \mathrm{~mm}$-long section of the slide was screened for calcareous nannofossils using the optical petrographic microscope Olympus BX and identification followed the Nannotax3 systematic scheme available at http://ina.tmsoc.org/Nannotax3. Counts were converted into densities (coccoliths per gram) and the data were grouped in three clusters:

1. small placoliths, which include coccoliths of the placolithic type smaller than $3 \mu \mathrm{m}$, namely Emiliania huxleyi and small Gephyrocapsa (e.g. Gephyrocapsa ericsonii);

2. large neritic forms, which include larger that $3 \mu \mathrm{m}$ coccoliths of taxonomic groups with af- finity for the neritic coastal waters off Western Iberia (GUERREIRO et al. 2015), namely Coccolithus pelagicus, Helicosphaera carteri, Gephyrocapsa oceanica, Syracosphaera spp., Coronosphaera spp.;

3. large oceanic forms, which include Gephyrocapsa muellerae, Calcidiscus leptoporus and Umbilicosphaera spp.

A wood fragment found at $376 \mathrm{~cm}$ depth (i.e. $546 \mathrm{~cm} \mathrm{bmsl}$ ) was AMS ${ }^{14} \mathrm{C}$ dated at Beta Analytic Inc. The conventional date was calibrated with Oxcal 4.2 (BRONK RAMSEY et al., 2013) software using the IntCal13 atmospheric curve (REIMER et al. 2013). Hydrocarbon contamination of sediments during coring prevented ${ }^{14} \mathrm{C}$ dating of the particulate organic fraction.

\section{RESULTS}

Based on macroscopic observations, texture, organic and inorganic content, foraminifera and nannoplankton identification, four major depositional units were defined: Unit 1 from the base of the core at $750 \mathrm{~cm}$ (all core heights mentioned in this section are $\mathrm{bmsl}$ ) to $562 \mathrm{~cm}$; Unit 2 between $562 \mathrm{~cm}$ and $410 \mathrm{~cm}$, Unit 3 between $410 \mathrm{~cm}$ and $255 \mathrm{~cm}$, and; Unit 4 from $255 \mathrm{~cm}$ until the top of the core at $170 \mathrm{~cm}$. Unit 2 was further divided in 2 sub-units. Ceramic elements were found in Units 2 and 4.

The result of the radiocarbon date (Table 1; Fig. 6) points to three time intervals encompassing the $16^{\text {th }}$ to the $18^{\text {th }}$ centuries, and the intercept of the mean of the radiocarbon date with the calibration curve yielded $1647 \mathrm{cal} \mathrm{AD}$ at a depth of 546 $\mathrm{cm}$ (rounded to1650 cal AD from hereafter). This suggests that the sedimentary sequence cored by EDP1 accumulated in the northern margin of Tagus throughout, at least, 200 years. The presence of $17^{\text {th }}$ to $18^{\text {th }}$ century ceramic artefacts at depths above $562 \mathrm{~cm}$ (see below), together with the ${ }^{14} \mathrm{C}$ dating result at $546 \mathrm{~cm}$, point to a high sedimentation rate in this area of the estuary since, at least, the middle $17^{\text {th }}$ century.

Figure 7 presents the depth variations for $\mathrm{pH}$, total $\mathrm{OM}(\%), R p$ Index, $\mathrm{CaCO}_{3}(\%)$ and texture (\%ff) measured in sediments of EDP1 core. Variations in foraminifera density and diversity along the core are shown in figure 8 . Sedimentary units $1,2,3$ and 4 are represented in both figures.

Table 1. ${ }^{14} \mathrm{C}$ conventional and calibrated dates. Calibration was done using the IntCal13 atmospheric curve (REIMER et al.2013).

Tabela 1. Data de radiocarbono convencional e calibrada. Calibração feita pela curva atmosférica IntCal13 (REIMER et al. 2013).

\begin{tabular}{|l|l|l|l|l|l|l|}
\hline Sample & Lab. Reference & Type of sample & $\begin{array}{l}\text { Conventional } \\
\mathbf{1 4} \mathbf{C} \text { date }\end{array}$ & $\mathbf{\delta}^{\mathbf{1 3}} \mathbf{C}$ & $\begin{array}{l}\text { Calibrated date } \\
\text { (2 sigma 95\%) }\end{array}$ & Intercept point \\
\hline $\begin{array}{l}\text { ED P 1\#14 } \\
375-377\end{array}$ & Beta-426279 & wood fragment & $260 \pm 30$ & $-27.4 \%$ & $\begin{array}{l}1525-1555 \mathrm{cal} \mathrm{AD} \\
1630-1665 \mathrm{cal} \mathrm{AD} \\
1780-1795 \mathrm{cal} A D\end{array}$ & $1647 \mathrm{cal} \mathrm{AD}$ \\
\hline
\end{tabular}




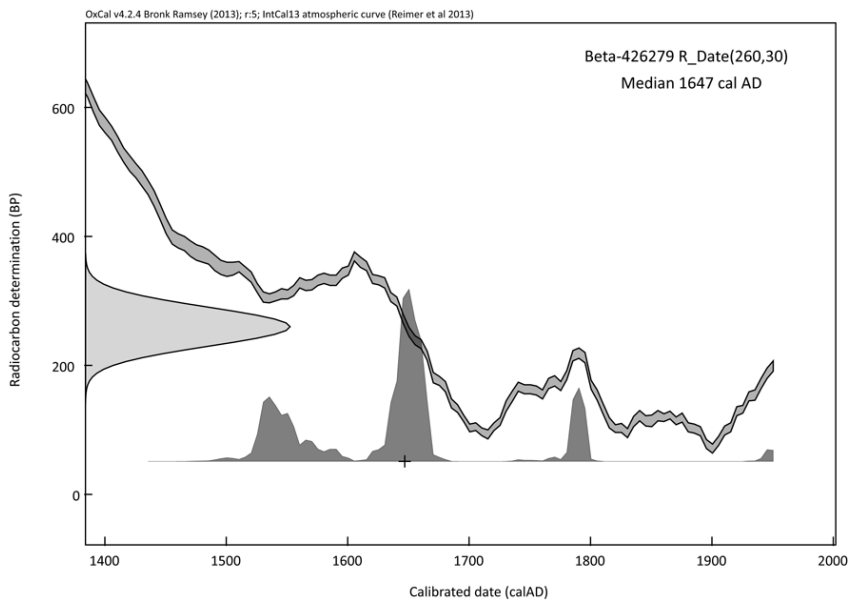

Fig. 6. Calibrated date. Calibration was done by Oxcal 4.2 (BRONK RAMSEY et al. 2013) software using the IntCal13 atmospheric curve (REIMER et al. 2013).

Fig. 6. Data calibrada. Calibração feita através do software Oxcal 4.2 (BRONK RAMSEY et al. 2013) com utilização da curva atmosférica IntCal13 (REIMER et al. 2013).

\section{Unit 1 (from $750 \mathrm{~cm}$ to $562 \mathrm{~cm} \mathrm{bmsl)}$}

This unit is essentially composed of subalkaline ( $\mathrm{pH}$ between 7.5 and 8.1) laminated dark grey mud (ff mean 94\%; max: 97\%; min: 90\%; Fig. 7) the coarse fraction being constituted by fine sandsized particles - quartz, muscovite>biotite, rare bivalve shell fragments, foraminifera, ostracods and fish bones. The $\mathrm{CaCO}_{3}$ content is low and shows small variations (max: 6.5\%; min: 2.6\%; mean: 3.6\%; Fig. 7) corresponding to the presence of bioclasts (Fig. 8). The total $\mathrm{OM}$ average is $6.7 \%$ (max: $7.8 \%$; $\min$ : $5.4 \%$ ) and the mean value of the Rp Index is 0.8 .

The foraminifera content presents low density and diversity. The assemblages are dominated by Ammonia beccarii (Linnaeus, 1758) (mean: 42\%) and Haynesina germanica (Ehrenberg, 1840) (mean: 35\%). Ammonia tepida (Cushman, 1926) reaches a significant presence in the analysed samples, between $17 \%$ at the base of this unit and $7 \%$ at the top. Cibicides lobatulus (Walker \& Jacob, 1798) and El- phidium williamsoni Haynes, 1973, are also present (with low significance, less than 5\%), but are absent at the top of this unit being replaced by Elphidium crispum (Linnaeus, 1758) and Bolivina pseudopunctata Hoeglund, 1947 as minor species, essentially grouped as Others. It must also be mentioned the low record of the planktonic foraminifera Globigerina sp. that slightly increases in the top of the unit (Fig. 8).

Calcareous nannofossils disclose their maximum abundance and diversity. All three clusters, small placoliths, neritic and oceanic forms show their maximum densities in this lower unit, with values oscillating but increasing until relative maximums are achieved just below $600 \mathrm{~cm} \mathrm{bmsl}$ (Fig. 9). It is interesting to note that small placoliths and these two groups do not peak exactly at the same levels indicating a degree of paleoecological succession in time. The end of this unit is marked by a sharp decrease in all three groups, more pronounced for the small and oceanic large placoliths groups.

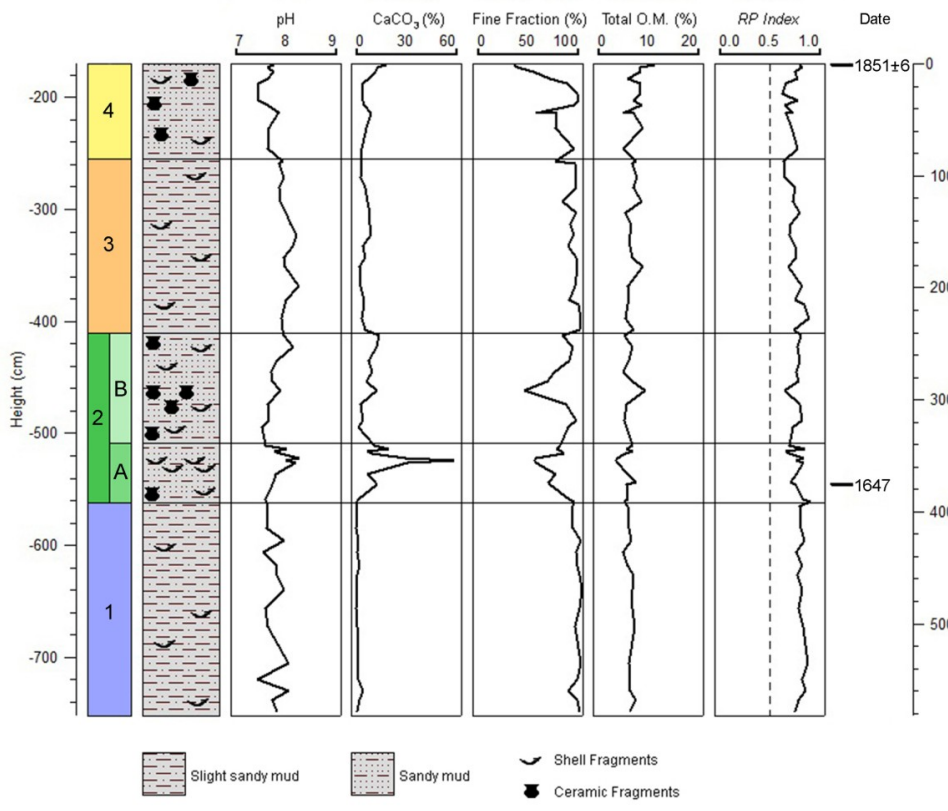

100 Fig. 7. Depth variation of $\mathrm{pH}$, calcium carbonate $\left(\mathrm{CaCO}_{3}\right)$, fine fraction (ff, $<63 \mu \mathrm{m})$, total organic matter $(\mathrm{OM}), R p$ Index and indication of the position of ${ }^{14} \mathrm{C}$ date. Depth below Aterro da Boavista. Height below mean sea level. 1647 refers E to a calibrated radiocarbon date (see Table 300 言 1 and Figure 6) and 1851 6 correspond to the temporal interval of Aterro da Boavista construction.

Fig. 7. Variação em profundidade do $\mathrm{pH}$, carbonato de cálcio $\left(\mathrm{CaCO}_{3}\right)$, fracção fina (ff; $<63 \mu \mathrm{m})$, matéria orgânica total $(\mathrm{OM})$, Index $R p$ com indicação da posição em profundidade da data calibrada. Depth corresponde à profundidade abaixo do Aterro da Boavista. Height corresponde à profundidade abaixo do nível médio do mar. 1647 corresponde à data calibrada (ver Tabela 1 e Figura 6) e $1851 \pm 6$ corresponde ao período temporal em que terá sido construído o Aterro da Boavista. 


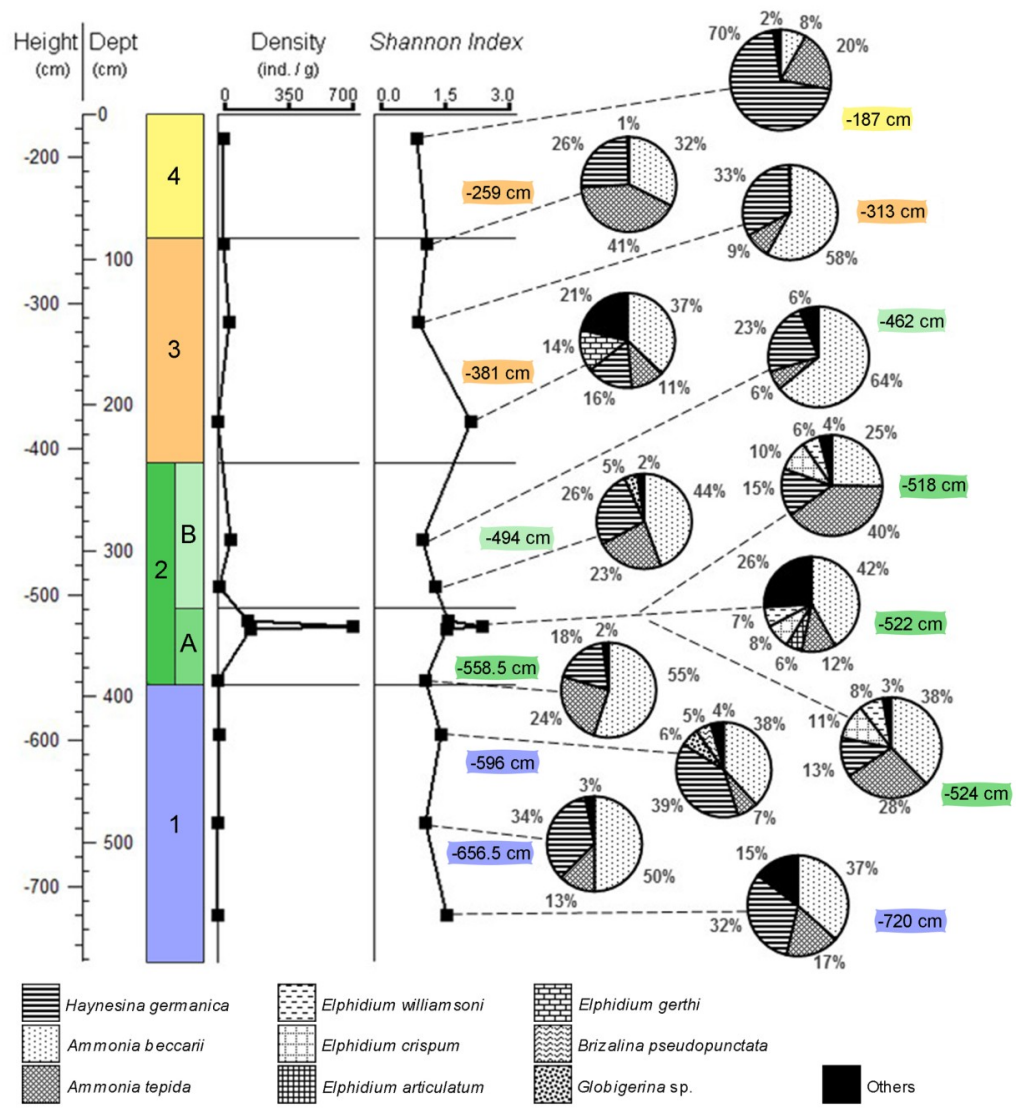

Fig. 8. Depth variation of foraminifera density (specimens/g) and diversity (Shannon Index). Depth below Aterro da Boavista. Height below mean sea level.

Fig. 8. Variação em profundidade da densidade (especimens/g) e diversidade (Shannon Index) de foraminíferos. Depth corresponde à profundidade abaixo do Aterro da Boavista. Height corresponde à profundidade abaixo do nível médio do mar.

\section{Unit 2 (from $562 \mathrm{~cm}$ to $410 \mathrm{~cm} b m s l$ )}

Unit 2 differs from Unit 1 in texture, $\mathrm{CaCO}_{3}$ content and abundance of anthropic elements. It was divided in 2 sub-units based in the calcium carbonate content (Fig. 7).

\section{Sub-unit 2A (from $562 \mathrm{~cm}$ to $509 \mathrm{~cm}$ )}

This sub-unit presents a decrease in the order of $20 \%$ in the average content of fine-grained particles (mean: 73\%; max: 92\%; min: 56\%; Fig. 7) and an increase in the bioclast's content (mean: 18\%; max: $56 \%$; min: $3 \%$ ) relatively to Unit 1 . The increment in $\mathrm{CaCO}_{3}$ is likely related with the high concentration of whole shells and shell fragments of different bivalve species (e.g. clams, cockle, oysters) and gastropods, rare spicules of echinoderms, ostracods and also with the high density of diverse species of foraminifera (Fig. 8), in particular at $524 \mathrm{~cm}$ where a peak in the calcium carbonate content was measured (corresponding with the maximum $\mathrm{CaCO}_{3}$ content measured in this unit and in the whole sedimentary column). This peak is coincident with an increase in the coarse fraction, probably reflecting the mentioned high content in shell fragments; the coarse fraction also includes very fine sand-sized quartz particles, muscovite, plant debris, charcoal and ceramics. The content in OM is similar to Unit 1 (mean: $6 \%$; max: $8 \%$; min: $4 \%$ ) and the $R p$ Index is just slightly lower (mean: 0.7). The sediment is sub-alkaline (mean: 7.9; max: 8.2; min: 7.6) with $\mathrm{pH}$ following the calcium carbonate trend (Fig. 7).

An increase in the foraminifera density together with a rise in diversity index was observed, particularly at $522 \mathrm{~cm}$. The dominant species are $A$. beccarii and $A$. tepida but the latter decreases substantially at $522 \mathrm{~cm}$ (Fig. 8). Haynesina germanica is also present at $524 \mathrm{~cm}$ and $518 \mathrm{~cm}$ (mean: 14\%) but is not represented at $522 \mathrm{~cm}$. Elphidium crispum, E. williamsoni and Elphidium articulatum (d' Orbigny, 1839) (only at $522 \mathrm{~cm}$ ) were also described in this sub-unit. Despite their low occurrence (often only 1 specimen of a single species) it is worth mentioning that the number of foraminifera species identified at $522 \mathrm{~cm}$ (29) markedly increases when compared with the underlying core sections, explaining the highest score of the diversity index (Fig. 8). The high content of different species in this sample makes the graphic representation difficult, so the less abundant species (lower than $5 \%$ ) were grouped in the class Others (with 


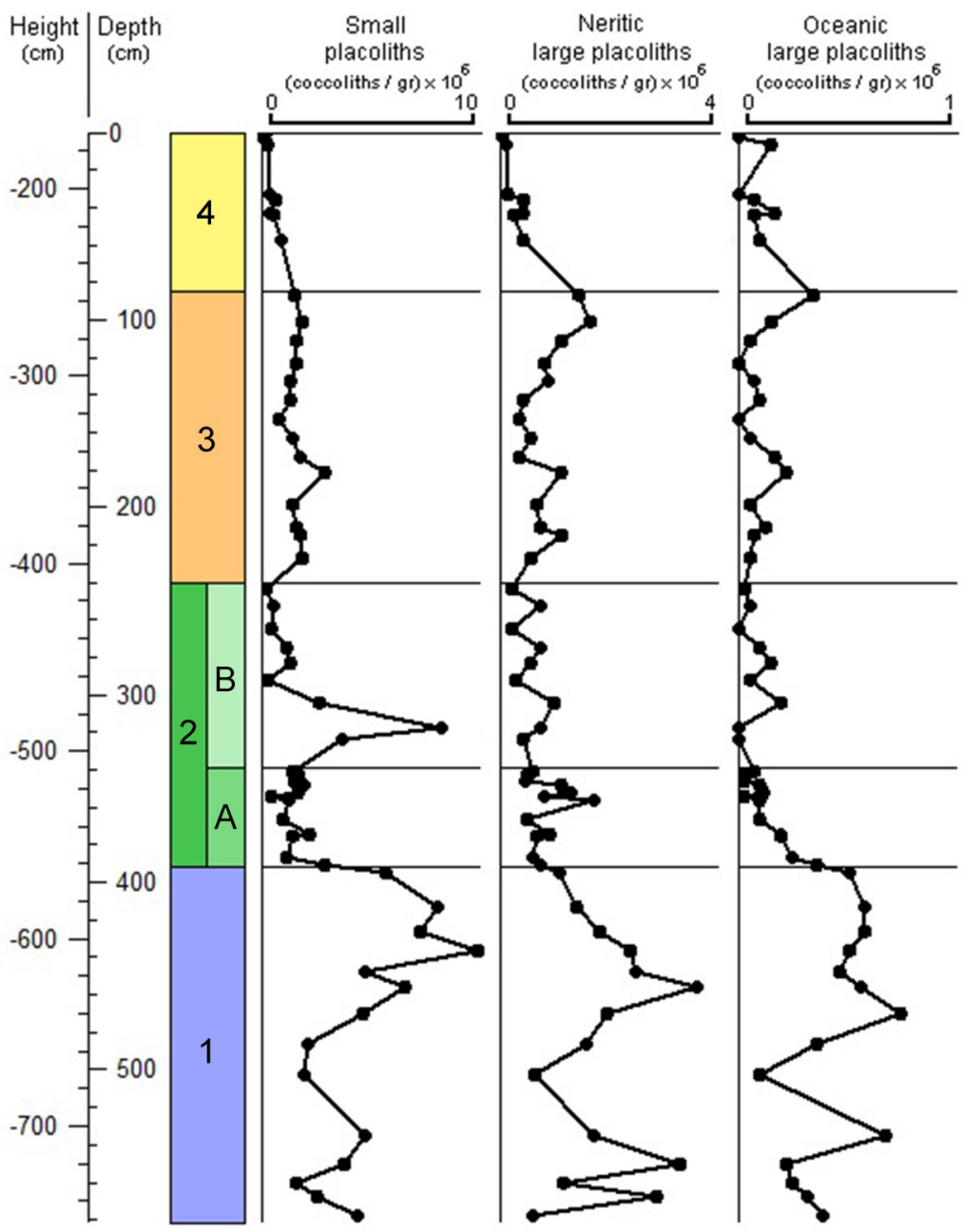

Fig. 9. Depth variation of densities of the three main calcareous nannofossil groups (see Materials and Methods for additional information on group's composition). Note scale variation between graphs. Depth below Aterro da Boavista. Height below mean sea level. Fig. 9. Variação em profundidade das densidades dos três principais grupos de nanofósseis calcários (ver a secção Materiais e Métodos para informações adicionais). A escala varia entre os diferentes gráficos. Depth corresponde à profundidade abaixo do Aterro da Boavista. Height

$26 \%$ density at this depth) (Fig. 8). Among this group it is important to refer the presence of Bolivina spathulata, (Williamson, 1858), Bolivina difformis (Williamson, 1848), Bolivina pseudoplicata Heron-Allen \& Earland, 1930, Bulimmina elongata d' Orbigny, 1826, Bulimina gibba Fornasini, 1902, Cassidulina obtuse Williamson, 1858, Nonion commune (d' Orbigny, 1846) that may occur under marine conditions associated to the river mouth channel and more often to the continental shelf. However, the base of this sub-unit presents a foraminiferal assemblage similar to the one of Unit 1.

During deposition of this sub-unit calcareous nannofossils experienced a significant drop, with values showing a slight peak (544 bmsl) only for the neritic group.

Sub-unit 2B (from $509 \mathrm{~cm}$ to $410 \mathrm{~cm} \mathrm{bmsl}$ )

This sub-unit is similar to Sub-unit $2 \mathrm{~A}$ concerning texture (ff mean: 76\%; max: 93\%; min.
$47 \%$ ) The coarse fraction is mainly composed by fine sand quartz particles, muscovite $>$ biotite, whole bivalve shells and shell fragments, foraminifera, ostracods and plant debris, the latter peaking at 463 $\mathrm{cm} \mathrm{bmsl}$, which translates in the profile of OM content $(9.3 \%$; Fig. 7). This sample also presents several centimetre-sized ceramic fragments. The calcium carbonate content is lower than in the preceding sub-unit, presenting a mean value of $10 \%$ (max: 15\%; min: 4\%), with lower values at the base and increasing upwards. The total OM is almost constant along the sub-unit with mean value around $7 \%$ (max: 9.3\%; min: 5.4\%). The $R p$ Index remains similar to Sub-unit $2 \mathrm{~A}$ (mean 0.7 ) with a slightly decrease to 0.6 at $463 \mathrm{~cm}$, corresponding to an increase in the OM labile fraction. $\mathrm{pH}$ increases up the sub-unit, varying between 7.6 and 8.1 (mean 7.8; sub-alkaline sediments), reflecting the same trend of the carbonate content. Signs of bioturbation have been recognized at the top of this sub-unit. 
The foraminiferal assemblage is dominated by A. beccarii, H. germanica and A. tepida. Globigerina sp. occurs in the base sample (5\%), decreasing to the top of the sub-unit (included in Others group); E. crispum is only present in the top sample as a minor species, counted in Others group (Fig. 8).

In this sub-unit calcareous nannofossils regain some importance and, once more, a cyclic synchronous pattern was found for both the more neritic and the more oceanic affine groups. The small placoliths reveal a sharp increase at the base of this sub-unit (Fig. 9).

\section{Unit 3 (from $410 \mathrm{~cm}$ to $255 \mathrm{~cm} \mathrm{bmsl}$ )}

This unit is characterized by dark grey muds (ff - mean: 90\%; max: 98\%; min: 75\%). The coarse fraction is composed by very fine quartz sand particles, bioclasts (whole shells and bivalve shell fragments, foraminifera, ostracod valves), muscovite $>$ biotite and plants debris. The OM content shows a constant record with mean value of $7 \%$ (max: 9\%; min: 6\%) and mean $R p$ Index of 0.7 , slightly decreasing upwards. The calcium carbonate content is lower in this unit with a mean value of $8 \%$ (max: $11 \%$; min: $4 \%$ ). Sediments are subalkaline (mean: 8 ; max: 8.2; min: 7.8).

In what concerns foraminifera, the $381 \mathrm{~cm}$ sample yielded low foraminifera density but high diversity, whereas the $313 \mathrm{~cm}$ sample presented higher density and lower diversity (Fig. 8). The foraminiferal assemblage is clearly dominated by $A$. beccarii followed by $H$. germanica, A. tepida and $E$. gerthi in a lower proportion (only at the base). A rare presence of Cancris auriculus (Fichtel \& Moll, 1798), Valvulineria bradyana (Fornasini, 1900), E. articulatum and other marine species, close to the base of this unit (Others; Fig. 8) explains the rise of diversity Shannon index. However these data must be interpreted carefully, because the total counting just reached 70 foraminifera and the proportion of those species may be unrepresentative.

Calcareous nannofossils continue with more modest densities and a small increment on all three groups at the very end of the unit (Fig. 9) was found.

\section{Unit 4 (from $255 \mathrm{~cm}$ to $170 \mathrm{~cm} \mathrm{bmsl)}$}

The top unit is characterized by coarser sediments (ff mean: $73 \%$; max: $95 \%$; $\min : 38 \%$ ), the coarse fraction increasing upwards. Coarse material is constituted by whole bivalve and gastropods shells and shell fragments, fine sand quartz particles and rare muscovite, plant debris, wood fragments, seeds and ceramic fragments. The OM content slightly increases upwards (mean: $8 \%$; max: $11 \%$; min: $5 \%$ ) just as the $R p$ Index (mean: 0.7 ) and $\mathrm{CaCO}_{3}$ content (mean: 10\%; max: 19\%; min: 6\%). Sediments are sub-alkaline $(\mathrm{pH}$ mean value: 7.7; max: 7.8; min: 7.5) (Fig. 7). In this unit Haynesina germanica clearly became the dominant species of the foraminiferal assemblage, followed by A. tepida and the lowest presence of $A$. beccarii (Fig. 8).

This unit is characterized by a marked decrease on the densities of all three groups of calcareous nannofossils although their presence still persists until the top (Fig. 9).

Altogether, these results are consistent with continuous decrease in depth and shift to an upper subtidal-low-intertidal sedimentation zone, where the activity of waves contributes to increase the energy level.

\section{DISCUSSION}

The EDP1 core drilled sediments accumulated in the northern margin of the Tagus estuary covering a timeline of, at least, 200 years. The uncertainty associated with this date derives from both the dating method and dated material (wood fragment), which can be older than the host sediment. However, ceramic fragments dated from the second half of the $17^{\text {th }}$ century or from the $18^{\text {th }}$ century occur around $557 \mathrm{~cm} \mathrm{bmsl}$, below the wood fragment. Given this, the sediment layer containing the dated wood, was most probably deposited in the second half of the $17^{\text {th }}$ century or in the $18^{\text {th }}$ century. The palaeoenvironmental interpretation suggests that deposition of Unit 1 occurred under a tidal regime and mean sea-level similar to the present day conditions. Despite the time period of its accumulation being at the moment unknown, this suggests that it corresponds to no more than a few centuries and changes in sediments throughout the core are related with variations in local constrains (e.g. water depth) rather than global forcing (e.g. sea-level changes).

EDP1 sediments were initially deposited under a water column of around $7.5 \mathrm{~m}$ (Unit 1) that was gradually reduced with the sedimentation process, and consequent siltation of the marginal estuarine bottom.

The $R p$ value is higher than 0.5 (indicating dominance of refractory organic matter over labile organic matter) throughout the core, suggesting an important proportion of phytoplankton (hardly degradable material; KRISTENSEN 1990) contribution to the total OM. However, some levels of Subunit 2B and Unit 3 yielded lower $R p$ Index values. This is interpreted as signing temporary increases in the labile fraction originated by time-discontinuous increments of organic materials with terrestrial origin (more degradable material). This corroborates the idea of a diminishing water column due to sedimentation and increasing shallowness bringing the study area closer to terrestrial sources of OM that could have been transported by rivulets meeting the estuarine margin or overland flow.

The presence of anthropic materials is evident in Unit 2 and Unit 4 also suggesting decreasing depth and increase of the proximity to an occupied estuarine margin, with time.

Unit 2 is distinctive by its contents in bioclasts and ceramics. Sub-unit 2A shows abundant 
whole shells and increase in the frequency of shell fragments and foraminifera density (Fig. 7 and 8). The foraminifera diversity also increases significantly, reflecting the presence of several species characteristics of shelf environment, that join the dominant subtidal estuarine assemblage. In Subunit 2B the abundance of both ceramics fragments $(>1 \mathrm{~cm})$ dated from the second half of the $17^{\text {th }}$ century $-18^{\text {th }}$ century, and of plant remains, increase. The low hydrodynamic conditions that prevailed during the deposition of the laminated estuarine muds of Unit 1 seem to have been disturbed by one or several short-lived events that contributed to increase the intensity of the marine signal in sediments of Sub-unit $2 \mathrm{~A}$ and deposited larger proportions of land-sourced debris in sediments of Sub-unit 2B. The chronological framing of Unit 2 allows considering the possibility of these materials, at least in part, having been originated by two events: the 1724 November $19^{\text {th }}$ storm (SARRAZOLA 2013) or the well known extreme tsunami resulting from the 1755 November $1^{\text {st }}$ earthquake. The thickness of these sub-units is high to be considered entirely determined by single events, especially when compared with onshore deposits of tsunamigenic/storm origin (e.g. ANDRADE et al., 2003; RAMOS-PEREIRA et al. 2013). A higher resolution approach to these sediments, with emphasis in some proxies like the foraminifera assemblages, will hopefully bring new insights to this subject.

Foraminifera assemblages presented in Unit 1 are concomitant with a deeper water column and higher marine influence in the estuarine core site during this depositional phase. The foraminifera dominant species of Units 3 and 4 reveal the return to brackish conditions but with less marine influence, probably due to depth reduction, resulting from the estuarine basin silt up. The natural sequence of deposition between Unit 1 and 3 was interrupted by the deposition of Unit 2, enriched in specimens derived mostly from shelf environments, as stated above. The enrichment in inner shelf foraminifera species was also recorded in two sediment layers described on a core collected in the southern Tagus margin (Alfeite core; ANDRADE et al. 2003) being those sediment layers associated with both the 1531 and 1755 tsunamis.

The calcareous nannofossil record is compatible with significant silt up of this sector of the Tagus northern river bank. The lowermost Unit 1 shows more frequent influence of marine waters entering the estuary with high content in advected coccoliths, from both the neritic and oceanic domains. Some samples from this unit contain complete coccospheres of gephyrocapsids ( $G$. oceanica and $G$. ericsonii) indicating conditions for these species to proliferate inside the estuary when the local water depth was at its maximum. The abrupt drop to significantly lower coccolith densities on all three groups during deposition of Unit 2 is com- patible with an increase in sedimentation rate leading to dilution of the fossil record (of around one order of magnitude for the small placoliths). In addition, the increase in energy may have contributed to inhibit deposition of these very small particles. The peak in small placoliths at the base of Sub-unit 2B also evidences a distinction between these two sub-units, corroborating the existence of more than one singular event of disturbance. The influence of marine waters is present towards the top of the core, more significant during Unit 3 and vestigial during Unit 4, compatible with shallowing local conditions.

Samples above and below the vessels Boavista 1 and Boavista 2 were not collected, precluding correlation between archaeological and geological stratigraphic units. However, the 1724 storm was described in coeval newspapers (Gazeta de Lisboa, $17247^{\text {th }}$ December, in SARRAzOLA 2013) as being an extremely intense event with strong waves breaking at Praia da Boavista and during which several vessels afloat in the estuary wrecked and have been lost. The eventual identification of Boavista 1 and Boavista 2 as two of the vessels shipwrecked by that storm could bring new insights in the correlation with the high-energy deposits recorded by EDP1 sediments. This line of investigation is, at present, under development by the nautical archaeological team.

\section{CONCLUSION}

Altogether, the results obtained from core EDP1 suggest that its base testifies sedimentation under brackish to marginal-marine conditions and low hydrodynamics predating $1650 \mathrm{cal}$ AD (Unit 1). This sediment was deposited in a subtidal bottom (most probably an accreting subtidal flat) under a water column of a few meters.

In the second half of the $17^{\text {th }}$ century $-18^{\text {th }}$ century higher energy conditions promoted rapid sedimentation of Unit 2. Two possible events (or both) can be identified as possible candidates to explain these disturbances: the extreme storm that hit the Lisbon region in November 1724, or the 1755 tsunami that extensively inundated the estuarine margins.

Brackish and low hydrodynamic conditions resumed during sedimentation of Unit 3 but the sediments are different from those of the basal unit in $\mathrm{OM}$ (with increase of terrestrial source) and bioclasts content. Unit 4, deposited in very shallow, higher energy, upper subtidal to lowintertidal conditions, corresponds to the interface between the natural sedimentation and humaninduced placement. In the middle $19^{\text {th }}$ century the Aterro da Boavista infill buried the subtidal - low intertidal estuarine sediments in order to create accommodation space for industrial and urban uses. 


\section{ACKNOWLEDGEMENTS}

Acknowledgements are due to $\mathrm{FCT}$ for $\mathrm{BI}$ grant SFRH/BI/51557/2011 of A. M. Costa and to Câmara Municipal de Lisboa (CML), in particular to Arquitecto J. Ramos de Carvalho and Arquitecto R. Ricardo, who made available the georeferenced historical maps of Lisbon (http:// 1xi.cm-lisboa.pt/ - Lisboa Interactiva - Câmara Municipal de Lisboa). The authors are also grateful to the students of the Geology Department (Lisbon University) L. Andrade, L. Correia and R. Pestana for help in the sedimentological work and to D. Rato, M.L. Fonseca, P. Santos, A. Silva, B. Fonseca, C. Morgado, C. Esteves, D. Simões, I. Andrade, J. Bernardo, J. Pessoa, K. Volochay, L. Centeno, M. Quininha, M. Silva, N. Hoska, and V. Pais for their contribution in foraminifera identification. Thanks are due to J. Raposo (Câmara Municipal do Seixal) for the study of some ceramic fragments, to all geo- and archaeo-team members that helped in collecting EDP1 core and to Pedro Costa e Anabela Cruces for their helpful comments.

\section{REFERENCES}

Almeida, I.M., Andrade, C., Freitas, M.C., Moreno, J., Cabral, M.C., Craveiro, S. \& Marques, F.M.S.F. 2009. Holocene paleoenvironmental evolution of the Lisbon downtown área as recorded in the Esteiro da Baixa sediments - first results. Journal of Coastal Research (proceedings of the 10th International Coastal Symposium), SI 56: 574-578.

AMARO, C. 1993. Vestígios materiais orientalizantes do claustro da Sé de Lisboa. In: Estudos Orientais IV - Os Fenícios no território Português, Lisboa, Instituto Oriental da Universidade Nova de Lisboa: 183-192.

Amaro, C. 1995. Núcleo Arqueológico da Rua dos Correeiros. Lisboa. Fundação Banco Comercial Português.

Andrade, C., Freitas, M.C., Miranda, J.M., Baptista, M.A., CACHÃo, M., Silva, P. \& MunhÁ, J. 2003. Recognizing possible tsunami sediments in the ultradissipative environment of the Tagus estuary (Portugal). Coastal Sediments'03 - The 5th International Symposium on Coastal Engineering and Science of Coastal Sediment Processes, 18-23 May, Clearwater Beach, Florida, CD-ROM, 14 p.

BLOT, M.L. 2003. Os portos na origem dos centros urbanos. Contributo para a arqueologia das cidades maritimas e flúvio-marítimas em Portugal. Lisboa. Trabalhos de Arqueologia 28, Instituto Português de Arqueologia.

Bronk Ramsey, C., Scott, M. \& Van der Plicht, H. 2013. Calibration for Archaeological and Environmental Terresrial Samples in the Time Range 26-50 ka cal BP. Radiocarbon, 55 (4): 2021-2027.

BUGALHÃo, J. 2001. A indústria romana de transformação e conserva de peixe em Olisipo. Núcleo arqueológico da Rua dos Correeiros. Lisboa. Trabalhos de Arqueologia 15, Instituto Português de Arqueologia.

BugALHÃo, J. 2008. Lisboa e a sua Arqueologia: uma realidade em mudança. ERA Arqueologia - revista de divulgação científica de estudos arqueológicos, 8: 217-230.

BugalHão, J. 2015. Núcleo arqueológico da Rua dos Correeiros. In: Uma casa pré-Pombalina na baixa lisboeta. Núcleo Arqueológico da Rua dos Correei- ros. Lisboa. CHAM. Arqueoarte, 3: 7-12.

CARDoso, J.L. 1995. O Bronze Final e a Idade do Ferro na região de Lisboa: um ensaio. Coimbra: Universidade de Coimbra. Conimbriga, 34: 33-74.

CostA, J.B. 1991. Caracterização e constituição do solo. Lisboa. Fundação Calouste Gulbenkian ( $4^{\mathrm{a}} \mathrm{Ed}$.)

Debenay, J.-P. 2012. A Guide to 1,000 Foraminifera from Southwestern Pacific: New Caledonia. Marseille. IRD Editions.

Diogo, A.M.D. \& TRINDADE, L. 1999. Ânforas e sigillatas tardias (claras, foceenses e cipriotas) provenientes das escavações de 1996/97 do teatro romano de Lisboa. Lisboa. Revista Portuguesa de Arqueologia, 2: 83-95.

FABIÃo, C. 1998. O vinho na Lusitânia: reflexões em torno de um problema arqueológico. Lisboa: IPA. Revista Portuguesa de Arqueologia, 1: 169-198.

FAtela, F. \& TABORDA, R. 2002. Confidence limits of species proportions in microfossil assemblages. Marine Micropaleontology, 45: 169-174.

FERREIRA, J. \& CACHÃo, M. 2003. Nanofósseis calcários em fácies costeiras: revisão de técnicas de estudo. Ciências da terra (UNL), Lisboa: esp. V, CD-ROM, A76-A78.

Filipe Folque, 1871. Carta Topográfica da Cidade de Lisboa levantada entre os anos 1856-58. Colecção Augusto Vieira da Silva n¹44. GEO/CML.

Flores, J.A. \& SierRo, F.J. 1997. Revised technique for calculation of calcareous nannofossil accumulations rates. Micropaleontology, 43: 321-324.

Guerreiro, C., Cachão, M., Pawlowsky-Glahn, V., Oliveira, A. \& Rodrigues, A. 2015. Compositional Data Analysis (CoDA) as a tool to study the (paleo)ecology of coccolithophores from coastalneritic settings off central Portugal. Sedimentary Geology, 319: 134 - 146.

Gutscher, M.A., Baptista, M.A., MirandA. J.M. 2006 The Gibraltar Arc seismogenic zone (part 2): constraints on a shallow east dipping fault plane source for the 1755 Lisbon earthquake provided by tsunami modeling and seismic intensity. Tectonophysics, 426:153-166.

KRISTENSEN, E. 1990. Characterization of biogenic organic matter by stepwise thermogravimetry (STG). Biogechemistry, 9: 135-159.

Loeblich, JR.A.R. \& TAPpan, H. 1988. Foraminiferal genera and their classification, New York. Van Nostrand Reinhold Company.

LNEC - Laboratório Nacional de Engenharia Civil. 1967. Especificação E 203, Solos - Determinação do pH Documentação normativa: $2 \mathrm{p}$.

Miranda, J., Batlló, J., Ferreira, H., Matias, L.M. \& BAPTISTA, M.A. 2012. The 1531 Lisbon earthquake and tsunami. Paper 0685 - 15 World Conference on Earthquake Engineering, 23-27 Sepetember, Lisbon, $9 \mathrm{p}$.

MOTA-ENGIL, 2012. Nova Sede da EDP, Prospecção geotécnica complementar, Sondagem n ${ }^{\circ}$ SC6, $4 \mathrm{p}$. 
A.M. Costa, M.C. Freitas, M. Inácio, F. Fatela, V. Lopes, C. Andrade, M. Cachão, P.M. Mendes, A. Sarrazola, M. Macedo, J. Bettencourt, R. Carvalho \& T. Freitas

MurRay, J.W. 1971. An Atlas of British Recent Foraminiferids. London. Heinemann Educational Books Ltd.

Murray, J.W. 2006. Ecology and Applications of Benthic Foraminifera. London. Cambridge University Press: 7-26.

MurRAY, J.W. 2007. Biodiversity of living benthic foraminifera: How many species are there? Marine Micropaleontology, 64: 163-176.

OliveIRA, J.C. 2012. Cartografia de Lisboa no Gabinete de Estudos Olisiponenses. Relatório de estágio. Faculdade de Ciências Sociais e Humanas, Universidade Lusófona de Humanidades e Tecnologias.

Pais, J., Moniz, C., Cabral, J., Cardoso, J.L., Legoinha, P., Machado, S., Morais, M.A., LourenÇo, C., Ribeiro, M.L., Henriques, P. \& Falé, P. 2006. Carta Geológica de Portugal na escala 1:50000, Noticia Explicativa da Folha 34-D. Lisboa. Instituto Nacional de Engenharia, Tecnologia e Inovação.

Ramos-Pereira, A., Trindade, J. \& AraúJo-Gomes, J. 2013. Seismite and Tsunamiite in Urban Environment. Finisterra, XLVIII, 95: 141-147.

Reimer, P. J., BARD, E., BAYliss, A., BeCK, J. W., BlaCKwell, P. G., Bronk Ramsey, C., Grootes, P. M.,
Guilderson, T. P., Haflidason, H., Hajdas, I., Hatt, C., Heaton, T. J., Hoffmann, D. L., HogG, A. G., Hughen, K. A., Kaiser, K. F., Kromer, B., MANNING, S. W., NiU, M., REIMER, R. W., RichARDS, D. A., Scott, E. M., Southon, J. R., StafF, R. A., Turney, C. S. M. \& VAN DER Plicht, J. 2013. IntCal13 and Marine13 Radiocarbon Age Calibration Curves 0-50,000 Years cal BP. Radiocarbon, 55 (4): 1869-1887.

SARrazolA, A. 2013. A grande tempestade de 19 de Novembro de 1724. Subsídio para uma abordagem narrativa. Apontamentos de Arqueologia e Património, 9: 83-88.

Sarrazola, A., Bettencourt, J.A., Teixeira, A. 2013. Lisboa Ribeirinha: evidências arqueológicas de uma vocação marítima milenar. Lisboa. DGPC, Revista Património, 1: 141-146.

SHANNON, C.E. 1948. A mathematical theory of communication. Bell System Technical Journal, 27: 379-423.

SousA, E. 2014. A ocupação pré-romana da foz do estuário do Tejo. Lisboa: UNIARQ. Estudos \& Memórias, 7.

Unknown author. 1844. Planta de Lisboa. Colecção Augusto Vieira da Silva $n^{\circ} 133$. GEO/CML 